JURNAL PENJAMINAN MUTU

LEMBAGA PENJAMINAN MUTU

UNIVERSITAS HINDU NEGERI

I GUSTI BAGUS SUGRIWA DENPASAR

\title{
PENDIDIKAN KARAKTER MEMPERKUAT EKSISTENSI PENDIDIKAN AGAMA HINDU PADA ERA INDUSTRI 4.0
}

\author{
Oleh \\ Ni Putu Ratni' ${ }^{1}$ I Nyoman Sueca ${ }^{2}$ \\ 1)2) Universitas Hindu Negeri I Gusti Bagus Sugriwa \\ puturatnii@gmail.com ${ }^{1}$, inyomansueca64@gmail.com ${ }^{2}$
}

diterima 22 Maret 2021, direvisi 16 April 2021, diterbitkan 31 Agustus 2021

\begin{abstract}
Abstrack
This article is based on research that aims to align Hindu education with industrial development 4.0, which is an era of disruption in order to make it able to answer challenges also able to overcome the massive obstacles of Hindu education implementation without losing the essence of it. The research has been conducted by a qualitative approach; data were collected by the technique of observation, interview, documentation, and literature study; the data analysis utilized descriptive technique. The result of the research showed there are three important things that Hindu education needs to attempt, those are (1) switching the old mindset which is chained by the bureaucratic become the disruptive mindset that put cooperative ways forward, (2) applying self-driving in order to create reforms as the demand of 4.0 era, (3) has to be able to develop a digital basis new service system. Finally, it can be concluded that science and technology development in the global age delivers challenges and obstacles to Hindu education which also continues to develop and change. Therefore, Hindu education in this disruption revolution era 4.0 has been demanded to be sensitive to community social changing phenomenons, willing to do self-disruption through character education because if it persistence to stay on the old method and management also being sealed from the dynamic world, its existence will be slumped and underdeveloped.
\end{abstract}

\section{Keyword : Hindu Education, Industry 4.0, Disruption.}

\section{PENDAHULUAN}

Ilmu pengetahuan dan teknologi yang berkembang pada zaman global memberikan tantangan dan hambatan terhadap pendidikan Hindu yang juga terus mengalami perkembangan dan perubahan. Pada beberapa dekade zaman saat berkembangnya Hindu di Nusantara, percakapan akrab siswa dengan guru dianggap tabu (merupakan pantangan), tetapi kini hal semacam itu justru menjadi sesuatu yang wajar, bahkan merupakan suatu keharusan dalam pandangan teori pendidikan 
modern. Artinya, hubungan seperti ini bahkan dianggap ciri atau bukti bahwa kegiatan pembelajaran telah berhasil. Hal lain yang juga telah bergeser adalah bidang penerapan metode pembelajaran. Pada masa pendidikan Hindu tradisional yang bertahan pada kearifan lokal, seorang pendidik merupakan figur utama dalam proses belajar dan mengajar yang mesti ditiru dan digugu. Pada masa itu guru menjadi sumber ilmu pengetahuan utama dalam pembelajaran di kelas, bahkan bisa dinyatakan sebagai teladan tunggal, sementara dalam konteks pendidikan Hindu modern, hal itu tidak berlaku lagi. Kini peran guru telah mengalami pergeseran, yaitu sebagai penyedia fasilitas dan perantara bagi siswa. Artinya, pembelajaran tidak lagi berfokus kepada guru (teacher centered), tetapi lebih berpusat kepada siswa (student centered). Dalam hal ini keberhasilan guru ditandai dengan kemampuan guru untuk memperkokoh dan mengembangkan kepribadian positif siswa pada saat melakukan aktivitas pembelajaran, di samping harus mampu membangun kemandirian siswa. Pergeseran hal-hal dalam gambaran tersebut adalah keniscayaan yang tidak mungkin dapat dielakkan sebagai suatu akibat terjadinya perubahan pada kebutuhan dan kepentingan manusia dari waktu ke waktu.

Perubahan kebutuhan dan kepentingan mendorong semakin kuatnya tuntutan kebermanfaatan hasil dari suatu proses pendidikan dalam suatu lembaga. Lulusan suatu lembaga pendidikan yang memiliki pengetahuan luas akibat pesatnya perkembangan teknologi belum tentu mampu menunjukkan kemampuan maksimal ketika harus berkompetisi di tingkat global seperti saat ini. Untuk memaksimalkan bahkan mengoptimalkan kemampuan lulusan agar siap terjun ke dalam kompetisi tingkat global, perlu diupayakan cara-cara memacu kompetensi para peserta didik yang salah satunya adalah dengan mengedepankan dan mengelola pendidikan karakter dengan lebih serius. Pada masa kini, pendidikan karakter memang masih mampu memberikan kekuatan terhadap eksistensi pendidikan agama Hindu.
Pendidikan karakter sangatlah penting dalam membentuk kompetensi dan life skill lulusan yang sesuai dengan kebutuhan dunia pasar karena jika keselarasan antara potensi lulusan dengan kebutuhan pasar tidak tercapai, lulusan pendidikan akan tertindas dan tersingkirkan, terutama ketika dunia memasuki era baru, yaitu era revolusi industri 4.0.

Era revolusi industri 4.0 memberi pengaruh yang cukup kompleks terhadap semua aspek kehidupan manusia, termasuk aspek ekonomi dan pendidikan. Era ini ditandai oleh peran sentral yang dimainkan teknologi cyber (dunia maya) dalam kehidupan manusia sehingga tidak mengherankan bahwa dalam dunia pendidikanpun muncul istilah pendidikan 4.0.

Pada hakekatnya pendidikan 4.0 (education 4.0) merupakan istilah yang saat ini sudah umum digunakan oleh para ahli teori pendidikan untuk menggambaran tentang pelbagai upaya untuk mengintegrasikan teknologi cyber, baik secara fisik maupun bukan fisik, ke dalam pembelajaran (Agus, 2017). Pendidikan 4.0 merupakan fenomena yang mucul sebagai respon terhadap kebutuhan munculnya revolusi industri keempat, yaitu industri yang mengkombinasikan peran manusia dan mesin yang saling terhubung dengan memanfaatkan penyatuan dunia nyata dengan dunia virtual. Dalam perkembangannya yang sangat cepat, era revolusi 4.0 menunjukkan bahwa tenaga mesin berperan lebih dominan dibandingkan dengan tenaga manusia sehingga memunculkan tantangan-tantangan baru di setiap aspek kehidupan yang menuntut agar kita bisa mempersiapkan diri untuk menyamakan diri dengan ritme perkembangannya. Hal yang sama berlaku dalam perkembangan industri 4.0 pendidikan Hindu yang juga diharapkan mampu menjawab tantangan dan mengatasi berbagai hambatan yang sangat besar.

Upaya Pendidikan Hindu dalam menjawab dan mengatasi tantangan dan hambatan dalam menyamakan ritme perkembangan sehingga memiliki kreteria pendidikan 4.0 di era revolusi industri saat ini 
yang selalu menuntut kemampuan berinovasi perlu diwujudkan melalui reformasi demi kemajuan dan peningkatan kesadaran di tubuh pendidikan Hindu. Reformasi yang harus diselaraskan dengan fakta bahwa selama ini pendidikan Hindu telah mengedepankan pendidikan karakter yang ditanamkan baik secara formal, informal, maupun non formal juga dituntut di dalam tubuh lembaga pendidikan tinggi formal seperti Universitas Hindu Negeri I Gusti Bagus Sugriwa.

Universitas Hindu Negeri I Gusti Bagus Sugriwa sebagai wadah pencetak SDM yang bergelut dalam bidang pendidikan Hindu yang dihadapkan pada tantangan, tuntutan, dan kebutuhan baru perlu melaksanakan upaya inovasi dan memperbarui sistem, pengelolaan, kurikulum, kemampuan tenaga pendidik dan kependidikan, sarana prasarana pembelajaran, serta budaya, kepribadian, etos kerja, dan peningkatan mutu pendidikan. Jika upaya semacam itu tidak segera dilakukan, pendidikan Hindu akan makin tertinggal dan tenggelam. Oleh karena itu, sangatlah penting untuk menemukan langkah-langkah konkret yang harus dilaksanakan dalam pendidikan Hindu agar tetap mampu bersaing pada era revolusi 4.0 disrupsi ini.

Untuk menemukan solusi tentang langkah-langkah konkret yang perlu dilaksanakan dalam pendidikan Hindu agar mampu berkompetisi di era revolusi 4.0 disrupsi ini, terdapat beberapa penelitian terdahulu yang menjadi tolak pikir dalam penelitian yang menjadi dasar penulisan artikel ini, yaitu: (1) hasil kajian Rokhman, Fathur dkk. (2014) berjudul Character Education for Golden Generation 2045 (National Character Building for Indonesian Golden Years) yang menyatakan bahwa apabila pendidikan telah menjadi bagian dari suatu upaya untuk membentuk karakter manusia yang unggul atau bisa dinyatakan siap untuk menerima perubahan global, maka secara mendasar, pada tahun 2045 Indonesia akan dapat menjadi bangsa yang kuat dalam segala aspek. Hal ini disokong oleh kondisi Indonesia yang mempercayai bahwa perkembangan generasi penerus bangsa yang mempunyai kemampuan untuk mewujudkan
Indonesia menjadi bangsa yang kuat pada tahun 2045 akan dapat dicapai. Keberhasilan tersebut akan bisa diwujudkan apabila sektor pendidikan di Indonesia mampu merefleksikan sejumlah nilai penting pendorong pembangunan generasi muda yang memiliki karakter bangsa, yaitu bangsa Indonesia; dan (2) hasil penelitian Putri (2018), berjudul "Pendidikan Karakter pada Anak Sekolah Dasar di Era Digital" yang menekankan bahwa pada era digital sekarang ini keluarga, guru, dan masyarakat sekitar memiliki peran sangat penting dalam upaya peningkatan karakter calon penerus bangsa, keluarga merupakan lokasi utama dan pertama bagi peserta didik dalam menjalani kehidupan. Oleh karena itu, di dalam keluarga perlu diadakan upaya pengawasan dan bimbingan kepada setiap anak yang dilakukan dengan penuh cinta kasih, tegas, dan teliti. Selain itu, pihak guru juga berperan dalam upaya pembentukan karakter dan kepribadian peserta didik agar selalu meningkat, semakin kompleks, dan bermakna. Artinya, guru tidak hanya mentransfer konsep tentang karakter yang baik, tetapi juga disertai arahan agar peserta didik selalu mampu merealisasikan dalam kehidupam keseharian. Di samping itu, guru juga merupakan panutan sehingga seorang guru wajib mengaplikasikan karakter yang baik pada kehidupan dirinya. Di pihak lain, masyarakat sekitar juga memiliki peran dalam melakukan pengawasan dan memberikan motivasi demi berkembangnya karakter peserta didik secara maksimal.

Kedua penelitian tersebut mengkaji tentang pendidikan karakter sedangakan penelitian yang menjadi dasar penulisan artikel ini akan secara spesifik mengkaji pendidikan karakter dalam upaya memperkuat keberadaan (eksistensi) pendidikan agama Hindu pada era industri 4.0.

\section{PEMBAHASAN}

\subsection{Peran dan Tujuan Pendidikan Agama Hindu}

Inti ajaran agama Hindu sesungguhnya terdiri atas tri kerangka agama Hindu, yaitu tattwa, susila, dan upacara. Ketiga bagian ini 
dikembangkan menjadi beberapa ajaran agama Hindu yang juga diaplikasikan dalam praktik upacara atau simbol-simbol yang mencerminkan makna ajaran tersebut. Keseluruhan dari esensi ajaran Hindu selama ini telah dituangkan dalam poin-poin materi pembelajaran agama Hindu agar dapat dipahami oleh peserta didik pada khususnya, umat Hindu pada umumnya.

Dalam penerapannya, pendidikan agama Hindu disampaikan melalui tiga jalur, yaitu pendidikan informal, pendidikan formal, dan pendidkan nonformal. Pendidikan agama secara informal adalah pendidikan yang diberikan dalam keseharian di lingkungan keluarga, pendidikan formal adalah pendidkan yang diperoleh melalui proses pembelajaran agama Hindu yang diberikan oleh guru di sekolah yang cenderung bersifat teoretis, sedangkan pendidikan agama nonformal berarti bahwa secara umum agama dipelajari di masyarakat melalui segala bentuk kegiatan keagamaan termasuk dilembaga-lembaga non formal seperti pasraman.

Arah dan tujuan pendidikan agama Hindu, yaitu memberikan pemahaman sekaligus mendorong transformasi nilai-nilai pendidikan agama agar peserta didik mempunyai kepribadian yang utuh dan berbudi pekerti yang luhur. Selain itu, komitmen pendidikan agama Hindu juga mendorong munculnya kesadaran peserta didik kesejatian diri (self realizing). Secara umum terdapat penggambaran bahwa pendidikan adalah sesuatu yang masih tertinggal pada diri seseorang setelah semua hal lain terlupakan. Artinya, dalam seluruh perjalan hidup seseorang yang telah mengalami banyak pengalaman hidup dan menerima banyak menerima pemahaman akan teori-teori yang hampir sebagian besarnya terlupakan, maka hal yang seharusnya akan tetap tertinggal di dalam diri adalah watak/karakter yang baik. Jadi, tanpa adanya watak atau budi pekerti yang baik, maka pendidikan tidak ada gunanya (Departemen Agama, 2003).

Menurut Bhagawan Sri Sathya Sai Baba (2000:5) karakter anak didik dapat dibentuk sesuai dengan kreteria tujuan sebagai berikut: (1) tujuan pengetahuan adalah kearifan; (2) tujuan peradaban adalah kesempurnaan; (3) tujuan kebijaksanaan adalah kebebasan; (4) tujuan pendidikan adalah untuk membentuk karakter anak yang baik. Tujuan pendidikan yang sesungguhnya harus mampu membentuk karakter peserta didik perlahan menjadi semakin kabur. Paradigma pendidikan pada era sekarang ini telah mengalami pergeseran dari upaya pembentukan karakter yang baik mengarah kepada pendidikan yang mengutamakan kemampuan intelektual semata. Hal ini menggambarkan bahwa banyak lembaga pendidikan yang telah mengalami perubahan fungsi komersil semata, yaitu menjadi pasar yang mendatangkan finansial melimpah secara cepat. Sementara itu, Menteri Riset dan Teknologi menegaskan bahwa peran gurupun tak kalah penting. Guru harus selalu terupdate dengan kondisi perkembangan ekonomi digital, perkembangan revolusi 4.0, dan perkembangan teknologi itu sendiri (Prodjo, 2020). Ketidak selarasan seluruh aspek sistem pendidikan akan berimbas pada gagalnya upaya pencapaian tujuan pendidikan itu sendiri.

Tujuan pendidikan agama Hindu telah dirumuskan oleh PHDI (2001) dalam Himpunan Keputusan Seminar Kesatuan Tafsir Terhadap Aspek-Aspek Agama Hindu, yaitu: (1) mengupayakan penanaman ajaran agama Hindu menjadi keyakinan dan landasan semua aktivitas umat Hindu dalam semua perikehidupannya; (2) agar ajaran agama Hindu memberikan arah pertumbuhan tata kemasyarakatan umat Hindu yang sejalan dengan Pancasila, dasar negara Republik Indonesia; (3) mengupayakan keserasian dan keseimbanga pelaksanaan bagian-bagian ajaran agama Hindu dalam masyarakat antara tattwa, susila, dan upacara; dan (4) mengembangkan hidup rukun antarumat beragama. Sementara itu, presiden pertama RI, Ir Soekarno yang benar-benar memahami pikiran Swami Vivekadanda menekankan bahwa tujuan Pendidikan adalah membentuk anak yang berkarakter atau anak yang suputra sebagaimana yang diidam-idamkan oleh 
orang tua, guru, dan masyarakat (Sari, 2016). Dengan demikian dapat dipahami bahwa tujuan pendidikan Hindu adalah untuk menggali nilai-nilai Hindu agar dapat diwarisi oleh regenerasi. Selain itu, pendidikan sesungguhnya juga ditujukan untuk membentuk peserta didik yang dapat berpikir lebih kreatif dan bertanggung jawab sehingga berguna bagi bangsa dan negara.

Apabila tujuan pendidikan, yaitu sebagai pembentukan karakter anak/peserta didik dapat dipahami, maka hal itu menunjukkan bahwa pendidikan bukan sebagai seperangkat nilai yang merupakan bagian dari sistem pendidikan, melainkan sebagai suatu proses yang merupakan bagian dari sistem kehidupan Hindu.

\subsection{Problematika Pendidikan Hindu pada Dunia Pendidikan di Indonesia}

Keberhasilan pembangunan bidang pendidikan pada seluruh provinsi di Indonesia menunjukkan dua kecenderungan. Pertama, terdapat keberhasilan pendidikan pada tingkat provinsi yang mencapai level di atas standar nasional. Kedua, terdapat juga provinsi yang belum mampu mencapai standar yang ditentukan secara nasional. Hal ini menunjukkan bahwa perbedaan kualitas pendidikan antar daerah di Indonesia masih sangat tinggi. Kualitas pendidikan antar daerah juga menunjukan perbedaan jika dilihat dari angka partisipasi, angka putus sekolah, angka mengulang kelas, rasio guru dan murid, guru dan sekolah, tingkat kelayakan guru, dan kondisi sarana prasarana sekolah. Artinya, perbedaan tersebut bersifat multidimensi.

Mencermati fenomena yang berlangsung pada masa kini, dapat disebutkan tiga penyebab pokok terjadinya ketimpangan mutu pendidikan yaitu: (1) terjadinya reduksi makna, bahkan degradasi fungsi pendidikan, yaitu hanya berupa aktivitas untuk menghafal teori dan terampil menyelesaikan soal ujian (UN); (2) pelaksanaan pendidikan mengarah kepada langkah pengomersilan, yaitu memperlakukan pendidikan sebagai suatu komoditas atau semacam barang dagangan utama yang diperjualbelikan. Di samping itu, pendidikan juga dikelola dengan sistem dunia industri, yaitu mengutamakan upaya mencari keuntungan (profit oriented); dan (3) pendidikan melahirkan kompetisi superioritas sekolah, yaitu ambisi sekolah untuk menjadi yang terunggul dan paling bergengsi dengan menekan orang tua murid untuk memberikan dukungan dalam bentuk berbagai pembiayaan sekolah yang ditentukan dengan berbagai alasan. Ketiga penyebab ketimpangan mutu pendidikan tersebut juga dialami oleh pendidikan Hindu sehingga eksistensi pendidikan Hindu yang hakiki semakin lama juga semakin mengalami pergeseran dari esensinya.

Eksistensi pendidikan Hindu sangat penting untuk dipertahankan karena telah menjadi suatu unsur yang sangat berperan dalam memberikan arah bagi perkembangan pola kemasyarakatan umat Hindu agar sesuai dengan nilai-nilai Pancasila. Selain itu, keberadaan pendidikan Hindu juga berperan dalam pembentukan budi pekerti peserta didik sehingga berguna bagi pembangunan bangsa, khususnya di Indonesia. Hal ini terutama dapat dilihat pada praktik pendidikan Hindu yang diselenggarakan oleh umat Hindu melalui lembaga-lembaga pendidikan tradisional yang sedang menjamur belakangan ini seperti pasraman-pasraman yang dibangun di bawah naungan Ditjen Bimas Hindu. Dengan memandang peran penting pendidikan Hindu dalam menjaga tatanan pri kehidupan di masyarakat, dapat dipahami bahwa ancaman eksistensinya akan memberi pengaruh yang sangat tidak menguntungkan bagi bangsa, masyarakat Hindu pada khususnya. Meskipun demikian, kenyataan yang terjadi di lapangan menunjukkan bahwa pendidikan Hindupun mengalami ancaman penurunan kualitas dan mutunya.

Pada prinsipnya penurunan kualitas pendidikan Hindu di tanah air disebabkan karena munculnya berbagai permasalahan atau persoalan intern didalam sistem pendidikan Hindu itu sendiri. Selain itu, pendidikan Hindu juga merupakan bagian dari sistem pendidikan nasional. sehingga pada saat pendidikan nasional belum mencapai 
tujuan yang diharapkan oleh masyarakat akibat banyaknya tantangan dan persoalan yang harus dihadapi dan belum terselesaikan, maka mau tidak mau harus diakui bahwa pendidikan Hindu pun ikut mengalami kegagalan. Hal yang sama juga dirasakan oleh pendidikan islam sebagaimana dinyatakan oleh Priatmoko (2018) bahwa dikarenakan pendidikan Islam merupakan subsistem pendidikan nasional, maka ketika pendidikan nasional dinilai gagal karena masih banyaknya persoalan yang tak kunjung berhasil diselesaikan harus diakui bahwa itu juga merupakan kegagalan pendidikan Islam.

Beragamnya problematika pendidikan Hindu menuntut penanganan lebih serius agar tidak berlarut-larut mengganggu upaya mempertahankan bahkan meningkatkan mutu dan kualitas keluaran yang dihasilkan agar tetap sesuai dengan esensinya namun mampu bersaing dengan perkembangan zaman. Untuk dapat mencari solusi atas problematika yang menjadi tantangan bagi pendidikan Hindu, tentunya terlebih dahulu perlu dipahami darimana saja sumber munculnya problematika tersebut.

Apabila diperhatikan secara saksama, problematika yang dihadapi pendidikan Hindu bisa diklasifikasikan menjadi dua sumber, yaitu problematika yang berasal dari agama Hindu sendiri (dari dalam atau internal) dan permasalahan yang berasal dari pihak di luar agama Hindu (eksternal). Problematika internal (dari dalam) dapat dilihat pada sistem dan metode pendidikan Hindu dewasa ini, misalnya tampak dalam pelaksanaan proses pembelajaran di institusi pendidikan Hindu yang dikelola, seperti pasraman, sekolah, dan perguruan tinggi Hindu, seperti Universitas Hindu Negeri (UHN) I Gusti Bagus Sugriwa. Lembaga pendidikan Hindu formal maupun non formal sebagian besar hingga saat ini masih menerapkan sistem pendidikan aguron-guron sebagaimana sistem pendidikan yang digambarkan dalam Itihasa dan Purana. Sesungguhnya hal itu cukup menggembirakan karena masih terdapat sentuhan sistem pendidikan Hindu dalam penerapannya, meskipun keilmuan Hindu lain yang berorientasi kepada sains dan teknologi masih sangat langka.

Namun mengingat metode penyampaian pendidikan Hindu masih menggunakan metode lama yaitu metode ceramah, penguatan eksistensi pendidikan Hindu menjadi kurang efektif karena pada dasarnya hal yang diperlukan saat industri 4.0 adalah pendidikan yang lebih mengedepankan metode daring dalam penanaman pendidikan karakter dengan memanfaatkan media gambar atau teknologi pendidikan. Artinya, para peserta didik perlu diberikan lebih banyak cerita lewat media gambar seperti penayangan film, baik Ramayana, Mahabharata, maupun film komedi, yang mengandung unsur etika religius. Di samping itu, peserta didik juga perlu dibekali dengan berbagai bentuk keterampilan diri bukan hanya sebatas teori semata dengan upaya serius untuk memperluas wawasan peserta didik.s

Pada saat ini kenyataan banyak menunjukkan bahwa wawasan mahasiswa Hindu di kalangan dunia industry 4.0 masih dapat dikategorikan masih sempit, penguasaan sains dan teknologi, komunikasi, dan politik juga belum maksimal sehingga dapat disimpulkan bahwa pendidikan Hindu yang diimplementasikan saat ini masih kurang memperhatikan link and match. Oleh karena itu, dalam membangun sistem pendidikan ke depannya, link and match harus betul-betul diperhatikan agar lulusan mampu menghadapi segala bentuk perubahan dan mampu memenangkan persaingan. Untuk memastikan implementasi pendidikan Hindu dapat dikategorikan mengikuti perkembangan zaman namun tetap mampu mengusung nilainilai esensi kehinduan tentunya tidak semudah membalikan telapak tangan.

Antara (2015) menyatakan bahwa ke depannya umat Hindu akan menghadapi tantangan yang cukup besar dan kompleks terutama permasalahan dalam adat dan awigawig desa yang mungkin berbenturan dengan tuntutan penyediaan sumber daya manusia Hindu yang lebih baik dan berkualitas serta mampu bersaing dengan sumber daya luar. Jika dibandingkan, pendidikan Hindu tentu sangat jauh tertinggal dari pendidikan di luar 
Hindu, meskipun dalam sejarahnya Hindu merupakan agama tertua di dunia. Salah satu yang menunjukkan bukti lemahnya pendidikan Hindu sehingga pemahaman Hindu tidak mengenai esensinya dan belum mampu bersaing dalam dinamika perubahan zaman adalah berubahnya persentase keyakinan umatnya yang dalam sejarahnya adalah mayoritas menjadi salah satu minoritasi di Indonesia. Sistem pendidikan yang diterapkan dalam pendidikan Hindu saat ini belum mampu mengangkat kembali kemajuan peradaban dan pendidikan yang dikuasai umat Hindu sebagaimana dideskripsikan dalam Itihasa maupun Purana bahkan seiring dengan waktu seolah terlupakan oleh umat Hindu sendiri sehingga berkesan bahwa umat lain lebih maju dalam peradaban dan perkembangannya melalui pendidikan.

Di luar konteks keagamaan, supremacy knowledge yang dikuasai oleh negara-negara maju yang lebih banyak mengedepankan logika daripada spiritualitas mengakibatkan banyak negara terus bergantung kepada mereka di hampir semua bidang kehidupan, baik bidang pertahanan dan persenjataan, komunikasi, informasi, ekonomi, perdagangan, maupun pendidikan dan pengembangan ilmu pengetahuan meskipun dari segi kebahagiaan sejati dan kedamaian masih sangat jauh capaiannnya.

Dengan melihat implementasi pendidikan di negara-negara maju, memang sangat tepat untuk mengembangkan pola pendidikan yang spiritual namun tetap berusaha untuk mengkemasnya dalam kemasan yang akan mampu menghasilkan lulusan yang mampu bersaing namun tetap menyadari esensi dari ajaran-ajaran agama itu sendiri yaitu untuk mewujudkan rasa damai dan kebahagiaan yang sesungguhnya. Untuk bisa lebih memahami langkah apa saja yang harus dilakukan untuk mewujudkan harapan semacam itu, hal pertama yang harus dilakukan adalah mengakui terlebih dahulu bahwa pendidikan Hindu memang masih mengalami ketertinggalan. Ketertinggalan itu setidaknya dapat dilihat dari ancaman eksistensi pendidikan agama tingkat menengah dan pasraman-pasraman saat ini.

Perbedaan kekuatan eksistensi tersebut dilihat dari kenyataan bahwa Itihasa dan Purana menggambarkan keberadaannya pada zaman Kreta, Treta, maupun Dwapara begitu kuat dan sangat penting serta memiliki peran sangat strategis dalam mengantarkan kemajuan pembangunan masyarakat. Selain itu, kecerdasan daya berpikir masyarakat juga sangat maju pada zaman tersebut. Berbeda dengan saat ini, gairah masyarakat untuk mengikuti pendidikan agama dan belajar di pasraman menunjukkan kecenderungan turun secara drastis. Dalam hal ini sikap pesimisme masyarakat terhadap pendidikan agama dan pasraman dapat dilihat dari adanya kekhawatiran universal terhadap terbatasnya kesempatan lulusan memasuki lapangan kerja modern. Artinya, lapangan kerja modern dianggap hanya terbuka bagi mereka yang memiliki kemampuan, keterampilan, dan penguasaan teknologi. Di pihak lain masyarakat melihat bahwa saat ini peluang kerja yang paling menjanjikan adalah dunia pariwisata. Hal tersebut menyebabkan kemauan masyarakat untuk menekuni pendidikan agama tergolong kecil. Sehubungan dengan itu, muncul kritik sebagaimana sering dilontarkan oleh pemikirpemikir Hindu bahwa pendidikan Hindu harus bangkit.

Pemikiran yang mengharapkan pendidikan Hindu harus kembali bangkit berdasarkan kenyataan yang telah diakui terlebih dahulu bahwa pendidikan Hindu saat ini tergolong tertinggal. Ketertinggalan itu lebih terlihat lagi saat dibandingkan dengan sistem pendidikan di negara-negara maju (negara Barat). Alasan ketertinggalan tersebut sesungguhnya adalah karena: (1) orientasi pendidikan Hindu masih berkutat hanya untuk mengetahui sesuatu melalui upaya transfer pengetahuan agama dan sebatas mengkhayalkan dunia rohani, sedangkan kemajuan teknologi melalui pemikiranpemikiran Hindu belum didalam dan belum diwujudkan; (2) praktik pendidikan Hindu masih menggunakan metode lama dan memelihara warisan lama. Artinya, 
pendidikan Hindu tidak menyentuh ilmu-ilmu klasik dan ilmu modern. Dalam hal ini sumber-sumber atau literatur yang dirujuk biasanya kitab suci saja. Selain itu, kitab suci dianggap sebagai ukuran baku dan primadona sebagai sumber inspirasi dalam menjawab semua persoalan kontemporer. Akan tetapi, kadang-kadang akibat tidak ditemukan jawaban dalam kitab suci tersebut, terpaksa harus diberikan jawaban yang tidak tepat atau dipaksakan; (3) umat Hindu masih sibuk dan hanya terbuai dengan kegiatan-kegiatan adat dan upacara keagamaan yang dijadikan kegiatan wajib. Artinya, kejayaan umat Hindu masa lampau yang tertuang dalam sejarah perkembangan agama sampai dengan saat ini masih mempengaruhi mindset umat Hindu di Indonesia. Mereka masih terkukung dengan kebanggaan akan kejayaan masa silam tanpa menyadari bahwa kebanggaan tersebut justru menyebabkan ketertinggalan terhadap kemajuan dalam pola berpikir. Hal tersebut sering mendorong banyak generasi muda untuk hanya berpangku tangan dan tidak berupaya untuk melakukan pembaruan, kalah cepat dengan perubahan sosial, politik, dan kemajuan iptek; dan (4) model pembelajaran pendidikan Hindu masih model lama. Pembelajaran dilakukan oleh guru dengan menekankan pada pendekatan intelektual verbalistik. Artinya, terjadi penegasan dalam hal hubungan edukatif dan komunikasi humanistik pendidik dengan peserta didik. Oleh karena iru, bisa dinyatakan bahwa sistem pendidikan Hindu masih mandul, terbelakang, dan mematikan daya kritis peserta didik. Dalam hal ini belum mencerdaskan dan belum dapat menyelesaikan masalah yang bersifat modern.

Implikasi model pembelajaran tersebut adalah terbelenggunya kreativitas peserta didik. Selain itu, pendidikan juga menjadi tercerabut dari esensinya. Semestinya pendidikan menjadi kekuatan untuk membebaskan peserta didik dari kebodohan. Hal tersebut dapat dilakukan melalui cara yang humanistik, yaitu menghargai kemampuan para peserta didik dan mengubahnya menjadi modal dasar untuk pengembangan potensi yang dimiliki di samping kepribadian peserta didik. Artinya, banyak persoalan dialami umat Hindu, baik secara internal maupun eksternal. Adapun persoalan dari dalam (internal) lain yang perlu secepatnya dicarikan solusi atau jalan keluar, misalnya umat Hindu masih terbelenggu dengan kegiatan-kegiatan adat sebagai kegiatan sosial di samping kegiatan keagamaan sebagai kegiatan yang bersifat kontinu. Di samping itu, juga sempitnya pemahaman terhadap esensi ajaran Hindu karena sifat gugon tuwon masih melekat. Dengan demikian, ketika membaca sumbersumber ajaran tidak terfokus pada keilmuan. Hal lainnya adalah orientasi format kurikulum tidak jelas, seolah-olah tidak disesuaikan dengan tingkat perkembangan peserta didik. Persoalan lain, yaitu kualitas tenaga pendidik dan kependidikan masih minim, sistem dan strategi yang dikembangkan, belum maju, metodologi dan evaluasi masih sederhana, serta pelaksanaan dan penyelenggaraan pendidikan agama Hindu masih bersifat eksklusif, yaitu belum mau berinteraksi dan bersinkronisasi dengan yang lain.

Permasalahan yang berasal dari pihak luar Hindu dalam pendidikan Hindu saat ini adalah kemajuan berbagai ilmu pengetahuan dan teknologi. Hal itu menimbulkan dampak pada lahirnya scientific kritisme terhadap pendeskripsian agama yang umumnya memiliki sifat menuruti tradisi, berdasarkan teks, dan konservatif. Selain itu, juga era globalisasi pada ranah informasi serta perubahan sosial ekonomi dan budaya dengan segala dampaknya, termasuk revolusi industri 4.0. Tantangan eksternal yang lain adalah dampak masyarakat beragama bersifat majemuk dan belum siap berbeda paham, bersikap fanatik absolutis, apologis, dan truth claim yang terbungkus dengan sifat-sifat iri hati, kepentingan pribadi, politis, atau sosiologis.

\subsection{Digitalisasi dan Otomatisasi pada Era Revolusi Industri 4.0}

Pemahaman definisi revolusi industri, dalam Kamus Besar Bahasa Indoneisa (KBBI) ditekankan bahwa revolusi berarti suatu perubahan yang bersifat sangat cepat, 
sedangkan industri diberikan arti usaha untuk melaksanakan proses produksi. Jika dipadukan, revolusi industri mengandung arti bahwa pada proses produksi terjadi perubahan yang sangat cepat. Perubahan yang cepat itu tidak saja bermaksud untuk menambah lebih banyak lagi barang yang dibuat (bertambah secara kuantitas), tetapi juga menaikkan atau menambah kualitas produk yang dihasilkan (meningkatkan kualitas). Istilah "revolusi industri" diperkenalkan oleh Friedrich Engels dan Louis Auguste Blanqui pada pertengahan abad kesembilan belas. Revolusi industri tersebut berlangsung dari waktu ke waktu. Pada dekade terakhir ini bisa dikatakan telah mencapai periode tingkat empat (4.0). Perubahan dari fase ke fase memberikan hal yang berbeda secara artikulatif dari segi fungsinya. Periode pertama (1.0) bertumpu pada penemuan mesin. Periode ini menekankan (stressing) pada mekanisasi produksi. Periode kedua (2.0) beranjak pada fase produksi massal. Pada periode ini telah terjadi integrasi dengan quality control di samping standardisasi. Periode ketiga (3.0) merupakan fase penyeragaman secara massal. Periode ini menekankan integrasi komputerisasi. Pada periode keempat (4.0) sudah dihadirkan digitalisasi dan otomatisasi, yaitu terjadi pemaduan antara internet dan manufaktur.

Buah revolusi industri 4.0, yaitu telah melahirkan gejala disruptive innovation. Dampak gejala ini sudah meluas dalam segala bidang kehidupan, yaitu mulai dari industri, ekonomi, pendidikan, politik, dan sebagainya. Selain itu, gejala ini juga sudah mampu mengubah gaya hidup (life style) dan pola pikir (mindset) warga dunia. Secara sederhana disruptive innovation bisa diberikan makna sebagai gejala terganggunya para pelaku industri lama (incumbent). Gangguan ini dilakukan oleh para pelaku industri baru berkat teknologi informasi mudah diaplikasikan. Banyak contoh dapat dikemukakan di sini, yakni menurunnya minat petani untuk menggarap sawah secara tradisional. Menurunnya minat itu tidak disebabkan oleh petani merasa malas, tetapi munculnya banyak pekerjaan sehingga sawah digarap dengan peralatan yang serba modern. Satu contoh lagi, yaitu terjadi penurunan penghasilan tukang ojek dan perusahaan taksi. Penghasilan yang menurun ini tidak disebabkan oleh menurunnya jumlah pemakai jasa ojek dan taksi, tetapi perilaku konsumen telah berubah. Dalam hal ini teknologi informasi yang telah maju berhasil memunculkan perusahaan jasa angkutan baru, yang berbasis online dan memanfaatkan laying perusahaan yang menggunakan alat komunikasi android. Artinya, sistem pemanfaatan jasa angkutan bersifat mudah dan tidak menuntut banyak biaya atau tarif. Keberadaan transportasi online ini mengakibatkan para incumbent jasa angkutan merugi. Contoh lain lagi adalah fenomena disruptive innovation. Fenomena ini juga menyebabkan beberapa pekerjaan tidak ada lagi sebab tergantikan mesin. Sekarang sebagian besar pekerja yang bertugas di konter check-in di pelbagai bandara internasional diganti oleh mesin yang dapat langsung menjawab kebutuhan penumpang. Dalam hal ini juga mencakup mesin pindai sebagai pemeriksa paspor dan visa. Selain itu, juga printer untuk mencetak boarding pass dan luggage tag. Dampak lainnya adalah bermunculan pekerjaan-pekerjaan baru yang sebelumnya tidak ada, seperti influencer, website developer, blogger, dan game developer.

Keuntungan munculnya disruptive innovation adalah sebagai berikut: (1) memudahkan konsumen memenuhi kebutuhan. Dalam hal ini perusahaan yang menggunakan teknologi terbaru mampu menekan biaya dengan cara memotong biaya yang dikeluarkan sehingga dapat menetapkan harga jauh lebih murah daripada perusahaan incumbent. Dengan demikian, biaya yang dikeluarkan oleh konsumen semakin murah. Hal itu menyebabkan konsumen semakin sejahtera; (2) dimudahkan oleh teknologi. Artinya, munculnya inovasi yang baru cenderung akan membawa teknologi yang baru dan canggih, setidaknya dibandingkan dengan teknologi yang telah lama ada. Oleh karena itu, dapat dikatakan terjadi transfer teknologi menuju yang lebih modern; (3) 
memacu persaingan berbasis inovasi. Indonesia merupakan negara yang tidak dapat makmur begitu saja tanpa inovasi. Dengan adanya inovasi yang mengganggu, perusahaan dalam industri dipaksa untuk melakukan inovasi sehingga secara terusmenerus memperbaiki layanannya; (4) mengurangi jumlah pengangguran. Inovasi yang dilakukan akan memberikan kesempatan lapangan kerja yang baru. Jika tidak dibuka lapangan baru, setidaknya lapangan kerja yang sudah ada dapat diperluas. Dalam hal ini inovasi dapat memberikan kesempatan kerja baru dengan upah yang lebih baik dibandingkan dengan lapangan pekerjaan yang sudah ada sebelumnya; dan (5) meningkatkan pertumbuhan ekonomi. Sesuai dengan teori Schumpeter bahwa teknologi yang mengganggu akan meningkatkan produktivitas akibat efisiensi. Kedua hal tersebut akan menambah mutu dan jumlah produk yang diproduksi. Di sisi lain, konsumsi masyarakat juga akan ditingkatkan oleh adanya inovasi atau pembaruan. Hal itu dimungkinlan karena sebelumnya pendapatan juga telah meningkat akibat muculnya perubahan yang besar. Perubahan tersebut menurut Rhenald Kasali merupakan akibat dari inovasi yang besar dan radikal (Sefudin \& Darwin, 2020).

\subsection{Menyongsong Pendidikan Hindu 4.0}

Disruptive innovation pada revolusi industri 4.0 menempatkan pendidikan Hindu di dua fase yang dapat dipilih salah satunya. Jika fase yang lama, yaitu bertahan dengan pola dan sistem lama dipilih, pendidikan Hindu harus rela dan berbesar hati jika berada dalam posisi semakin tertinggal, baik perkembangannya maupun kualitas pendidikannya. Sebaliknya, jika fase kedua yaitu fase baru yang dipilih, maka pendidikan Hindu harus membuka diri, terbuka terhadap era disrupsi dengan semua akibat penerapannya. Fase kedua akan memungkingkan mereka untuk dapat ikut berkompetisi dan memiliki kesempatan untuk menang dalam persaingan. Hasil penelitian
Mc. Kinsey menunjukkan bahwa akibat dari teknologi digital menuju revolusi industri 4.0 pada kurun waktu lima tahun ke depan adalah akan ada banyak pekerjaan mengalami pergeseran atau hilang dari muka bumi. Dari hasil riset ini diperoleh pesan bahwa semua orang yang berniat mempertahankan eksistensi diri pada persaingan tingkat dunia perlu menyiapkan mental di samping skill, artinya memiliki keunggulan bersaing (competitive advantage) lebih bagus daripada orang lain. Dalam hal ini jalan utama yang paling sederhana dapat dilakukan untuk mempersiapkan skiil adalah berperilaku yang baik (behavioral attitude), meningkatkan kemampuan diri, dan mempunyai kekuatan literasi. Semua hal itu bisa dicapai melalui jenjang pendidikan (long life education) (Suwardana, 2018). Di samping itu, juga diperlukan konsep diri yang dapat diperoleh lewat pengalaman bekerja sama antargenerasi/antardisiplin ilmu (experience is the best teacher). Berdasarkan penekanan tersebut dapat dipahami bahwa untuk meningkatkan mutu pendidikan Hindu diperlukan perubahan atau reformasi di institusi pendidikan Hindu.

Reformasi yang dimaksudkan tersebut adalah reformasi yang akan mampu memperkuat eksistensi pendidikan Hindu pada era 4.0. Reformasi yang harus dilaksanakan tersebut harus mampu berjalan selaras dengan menguatnya berbagai inovasi yang mengganggu jalannya sistem lama di dunia pendidikan Hindu. Hamid (2017) menjelaskan bahwa inovasi yang mengganggu merupakan sebuah alternatif yang menawarkan efisiensi namun keberadaannya tidak bisa semerta-merta memberikan hasil yang baik karena teknologi yang digunakan adalah teknologi yang belum ada sebelumnya. Kebaruannya inovasi tersebut tentu belum mempunyai aturan yang menjadi sebuah ketetapan tentang bagaimana teknologi tersebut harus bekerja meskipun inovasi di bidang pendidikan di era 4.0. merupakan lompatan kemajuan teknologi. Tekait dengan pemanfaatan lompatan inovasi semacam itu, reformasi yang perlu dilakukan terhadap pendidikan Hindu adalah 
pendisrupsian diri. Pendisrupsian diri dimaknai sebagai upaya penyesuaian diri terhadap kebutuhan dan tuntutan masyarakat di samping memiliki orientasi pada waktu mendatang. Pada dasarnya ketertinggalan pendidikan Hindu diakibatkan oleh problematika orientasi anak-anak muda pada pengaruh perkembangan pariwisata yang sangat pesat. Selain itu juga diakibatkan oleh adanya perbedaan kecepatan perkembangan ilmu pengetahuan dan teknologi dengan kecepatan perkembangan pendidikan di tubuh Hindu. Akibatnya, pendidikan Hindu belum mampu merespons dengan cepat dan tepat perubahan sosial masyarakat yang bersifat dinamis. Hal tersebut menunjukan suatu kesan keniscayaan bahwa proses pendidikan Hindu menjadi kurang kontekstual. Di pihak lain kebijakan yang diambil oleh Kementerian Pendidikan dan Kebudayaan (Kemendikbud) dan Kementerian Agama (Kemenag) kerap kali berbeda sehingga sering menjadi pemicu polemik, misalnya pengambilan kebijakan yang menyangkut masalah gaji, sertifikasi, dan insentif pendidik. Untuk menyongsong pendidikan Hindu 4.0, semua persoalan tersebut harus dicarikan jalan keluar. Jika tidak, pendidikan Hindu yang kontekstual terhadap zaman global akan sulit diwujudkan. Dengan demikian, diperlukan reformasi dan pembaruan terhadap semua aspek dalam pendidikan Hindu, baik tenaga pendidik, perencanaan pembelajaran, metode, maupun evaluasi pengajaran.

Pembaharuan terhadap setiap aspek pendidikan Hindu akan memberikan kebebasan dan akan mampu memacu motivasi positif bagi layanan pendidikan dan kependidikan yang lebih baik dan profesional. Sebagai contoh jika tenaga pendidik seperti guru mendapatkan reformasi yang inovatif dan disrupsi, maka guru tersebut akan merasa lebih bebas dan mudah melaksanakan tugas dan fungsinya di samping akan termotivasi untuk lebih proaktif memberikan pelayanan dalam konteks pembelajaran. Artinya, dalam aktivitas belajar mengajar yang terfokus pada upaya mentransfer pengetahuan dari guru kepada siswa dan terkungkung di kelas akan sulit dihasilkan lulusan yang memiliki daya saing tinggi. Kini model pembelajaran sudah mengalami perubahan, tidak lagi berorientasi pada teacher centered, tetapi bersifat student centered. Dalam hal ini guru diharapkan selalu lebih aktif sebagai fasilitator, memberikan tuntunan, dan pendampingan kepada peserta didik, misalnya guru pendidikan agama Hindu dapat memaksimalkan fungsi media sosial. Selain itu, sekarang sistem pengelolaan pendidikan Hindu harus mampu memanfaatkan kemajuan media komunikasi yang tersedia. Media sosial tidak hanya menjadi hiburan. Media sosial sudah berubah menjadi sarana komunikasi yang efektif, alat yang membantu dalam pekerjaan, dan merupakan ilham dalam melakukan inovasi. Peluang ini perlu digunakan secara baik, artinya tidak alergi terhadap perubahan. Hal itu penting karena pada era sekarang perubahan sudah merupakan kebutuhan. Jika suatu lembaga selalu bersifat statis dalam tata kelola yang lama, dapat dipastikan akan kalah bersaing dengan lembaga yang dikelola secara lebih dinamis. Sejalan dengan pemikiran tersebut Irawan (2018) menegaskan dalam orasi ilmiahnya bahwa generasi milenial (kelahiran sekitar 1980-2000) adalah generasi yang bergaul erat dengan teknologi dan informasi, yaitu melalui internet berselancar di dunia maya dalam memperoleh informasi dan berkomunikasi melalui sosial media. Mereka adalah generasi yang siap untuk memanfaatkan lompatan era 4.0. Meskipun demikian, pemanfaatan teknologi bukan berate meniadakan peran penting tenaga pendidik dalam pembangunan dan penguatan karakter positif peserta didik, seperti pengarahan, pembiasaan, keteladanan, penguatan, kedisiplinan. Nilai-nilai karakter yang bisa digali dalam pembelajaran seperti Religius, jujur, kerja keras, disiplin, rasa tanggung jawab, cinta tanah air, peduli terhadap lingkungan sekitar, jiwa sosial yang kuat tetap harus dikedepankan disamping peningkatan intelektualitasnya. Pengelolaan lembaga pendidikan yang dapat mensupport peran tenaga pendidik menjadi seoptimal mungkin secara dinamis tetap harus memperhatikan poin-poin sasaran pendidikan 
itu sendiri. Upaya mengelola institusi pendidikan Hindu harus mempunyai roadmap yang terperinci. Di samping itu, target yang direncanakan harus bersifat realistis. Dengan demikian, orientasi kurikulum dan visi pendidikan Hindu perlu segera dilakukan. Artinya, kurikulum, visi, program tahunan, dan program semester harus jelas, fleksibel, kontekstual, dan futuristic (berhubungan dengan masa depan). Kemampuankemampuan tersebut diperlukan terutama oleh pihak pemimpin dan pengelola institusi pendidikan Hindu.

Era 4.0 merupakan era yang menuntut kecepatan dan kemudahan manusia. Dalam hal ini upaya-upaya dan tata kelola lama yang bagus dan relevan harus disesuaikan dengan kondisi zaman yang telah berubah dan berkembang. Dalam pengelolaan pendidikan, penyesuaiannya harus dipersiapkan matangmatang untuk memperkecil kemungkinan kegagalan dalam pencapaian tujuan akhir dari pendidikan. Wahyudi (2020) menekankan bahwa learning is not just a routine educational activity but it is an educational communication that is full of messages, systemic, procedural, and laden aim. Therefore, he must be prepared carefully. Jadi proses pembelajaran bukanlah sekedar aktifitas pendidikan rutin, akan tetapi merupakan komunikasi pendidikan yang sarat dengan pesan-pesan, bersistem, berprosedur dan sarat dengan tujuan sehingga harus benarbenar direncanakan dan dipersiapkan dengan serius. Dalam tatanan pengelolaan dan keprofesian sumber daya manusia, misalnya, kompetensi dan kapasitasnya perlu diperkuat dan ditingkatkan. Hal itu dapat dilakukan melalui diklat, seminar, lokakarya, beasiswa studi, dan sebagainya. Proses pendidikan Hindu pada era revolusi 4.0 harus mampu mengembangkan sistem pelayanan baru berbasis digital. Artinya, warga lembaga pendidikan Hindu, baik di sekolah formal maupun pasraman yang dibangun masyarakat, dapat dengan leluasa mengakses segala keperluan terkait dengan proses pembelajaran dan pelayanan keadministrasian. Hal lainnya adalah pengembangan model pembelajaran masa kini melaui pemanfaatan teknologi digital secara penuh, seperti e-learning dan blended learning.

\section{KESIMPULAN}

Ilmu pengetahuan dan teknologi yang berkembang pada zaman global memberikan tantangan dan hambatan terhadap pendidikan Hindu yang juga terus mengalami perkembangan dan perubahan. Pada beberapa dekade zaman perkembangan Hindu di Nusantara, percakapan akrab siswa dengan guru dianggap sebagai hal yang tabu (merupakan pantangan). Namun saat ini hal tersebut justru menjadi sesuatu yang wajar, bahkan merupakan sesuatu yang sangat diharapkan atau diharuskan dalam pandangan teori pendidikan modern. Artinya, hubungan seperti itu bahkan merupakan petunjuk atau tanda bahwa proses pendidikan dapat dinyatakan telah berhasil.

Pendidikan Hindu pada era revolusi 4.0 disrupsi ini dituntut agar peka terhadap fenomena-fenomena perubahan sosial masyarakat. Jika ingin memperkuat eksistensinya, pendidikan Hindu pada era ini harus mau mendisrupsi diri. Artinya, jika tetap bersikeras pada metode dan tata kelola lama serta tertutup dari dunia yang terus berkembang, pendidikan Hindu akan semakin terpuruk dan terbelakang. Dengan demikian, ada tiga hal penting yang perlu diusahakan oleh pendidikan Hindu. Pertama, pola pikir lama yang terbelenggu aturan birokratis harus diubah menjadi mindset disruptif (disruptive mindset) yang mengedepankan cara-cara yang korporatif. Kedua, pendidikan Hindu juga perlu melaksanakan self-driving supaya dapat mengadakan pembaruan-pembaruan seperti yang dituntut oleh era 4.0. Ketiga, proses pendidikan Hindu harus mampu mengembangkan sistem pelayanan baru berbasis digital. Dalam hal ini warga lembaga pendidikan Hindu, baik di sekolah formal maupun pasrman yang dibangun masyarakat, dapat dengan leluasa mengakses segala keperluan terkait dengan proses pembelajaran dan pelayanan keadministrasian. Selain itu, semua segi di dalam pendidikan Hindu 
diupayakan supaya tetap kontekstual terhadap tuntutan dan perubahan.

\section{DAFTAR PUSTAKA}

Agus, M. (2017, Nivember 5). Pendidikan 4.0, Apa Itu? Retrieved Maret 7, 2021, from Eduaksi-Inspirasi Sekolah Indonesia: https://eduaksi.com/pendidikan-40 -apa/

Antara, I. S. (2015, Maret 11). Kepemimpinan dan Kelangsungan Hindu Kedepan. Retrieved Maret 6, 2021, from Kompasiana:

https://www.kompasiana.com/perad ah/552b31c3f17e614b7dd623c7/ke pemimpinan-dan-kelangsunganhindu-kedepan

Departemen Agama. (2003). Intisari Ajaran Hindu. Surabaya: Paramita.

Hamid, E. S. (2017, Juli 27). Disruptive Innovation: Manfaat Dan Kekurangan Dalam Konteks Pembangunan Ekonom. Retrieved Maret 7, 2021, from Fakultas Hukum Universitas Islam Indonesia: https://law.uii.ac.id/wpcontent/uploads/2017/07/2017-07-

27-fh-uii-semnas-disruptiveinnovation-manfaat-dankekurangan-dalam-kontekspembangunan-ekonomi-EdySuandi-Hamid.pdf

Irawan, J. F. (2018, Pebruari 9). Tantangan Bagi Perguruan Tinggi dalam Menyongsong Era Digital. Orasi Dies FE 63_2018_Tantangan bagi perguruan tinggi-p. Bandung, Jawa Barat, Indonesia: Universitas Katolik Parahyangan.

Kasali, R. (2017). Disruption. Jakarta: PT. Gramedia Pustaka Utama.

PHDI. (2001). Himpunan Keputusan Seminar Kesatuan Tafsir Terhadap AspekAspek Agama Hindu. Denpasar: Parisada Hindu Dharma Pusat.

Priatmoko, S. (2018). Memperkuat Eksistensi Pendidikan Islam di Era 4.0. TA"LIM : Jurnal Studi Pendidikan Islam Vol.1 No.2, 221-239.
Prodjo, A. W. (2020, Januari 16). di Era Revolusi Industri 4.0, Guru Harus Terus Menyesuaikan Diri. Retrieved Maret 7, 2021, from Kompas.com: Edukasi.Kompas.com/read/2020/01 /16/18130031/di-era-revolusiindustri-4.0-guru terus menyesuaikan.

Putri, D. (2018, Vol. 2 No. 1). Pendidikan Karakter Pada Anak Sekolah Dasar di Era Digital. AR-RIAYAH : Jurnal Pendidikan Dasar, pp. 37-50.

Putri, D. P. (2018). Pendidikan Karakter Pada Anak Sekolah Dasar di Era Digital. AR-RIAYAH : Jurnal Pendidikan Dasar vol. 2, no. 1, 37-50.

Rokhman, Fathur;dkk. (2014). Character Education For Golden Generation 2045 (National Character Building for Indonesian Golden Years). ScienceDirect, 1161 - 1165.

Sai Baba, B. (2000). Pembentukan Karakter yang Baik pada Anak Didik. Surabaya: Paramita.

Sari, D. K. (2016). Bingkai Pendidikan Islam di Mata Soekarno (Sebuah Resensi).

Pemikiran Pendidikan Islam Soekarno. Yogyakarta, D.I. Yogyakarta, Indonesia: Samudra Biru.

Sefudin, A., \& Darwin, M. (2020, Oktober Vol. 1 No. 2). Perbandingan Teori Disrupsi pada Marketing di Era Industri 4.0 Menurut Hermawan Kartajaya dan Rhenald Kasali. KOMITMEN: Jurnal Ilmiah Manajemen, pp. 25-39.

Suwardana, H. (2018). Revolusi Industri 4.0 Berbasis Revolusi Mental. Jati Unik Vol. 1 No.2, 109-118.

Wahyudi, A. (2020, Juni Vol. 08, No. 01). The Methodology of Development for Learning Implementation Planning in the Industrial Era 4.0. Edukasi, pp. 155 - 165. 